\title{
ANÁliSE CRÍTICA DA PERDA ALARGADA DE BENS À LUZ DA ORDEM JURÍDICA CONSTITUCIONAL BRASILEIRA
}

\author{
CRITICAL ANALYSIS OF THE ASSET EXTENDED COFISCATION IN THE LIGHT OF THE \\ BRAZILIAN CONSTITUTIONAL LEGAL ORDER
}

\section{Fabio Ramazzini Bechara}

\begin{abstract}
Professor dos Programas de Graduação e Mestrado/Doutorado em Direito Político e Econômico da Universidade Presbiteriana Mackenzie. Doutor em Direito pela Universidade de São Paulo. Mestre em Direito pela Pontifícia Universidade Católica de São Paulo. Pós-doutorado no Woodrow Wilson International Center for Scholars (EUA). Líder do Grupo de Pesquisa Direito Penal Econômico e Justiça Internacional (UPM). Promotor de Justiça em São Paulo.

E-mail: frbechara@hotmail.com
\end{abstract}

João Paulo Sales

Graduado em Direito pela Faculdade de Direito da Universidade Presbiteriana Mackenzie. Membro do Grupo de Pesquisa Direito Penal Econômico e Justiça Internacional (UPM). Advogado.

Email: j.p.sales@ hotmail.com

Recebido em: 11/05/2020

Aprovado em: 12/08/2020

RESUMO: O artigo tem por objetivo analisar a compatibilidade do instituto do confisco alargado de bens, introduzido pela Lei n. 13.964/2019, com a Constituição Federal Brasileira, enquanto instrumento eficaz para a prevenção e repressão ao crime organizado, notadamente com foco nas suas fontes de financiamento. $\mathrm{O}$ exame da constitucionalidade decorre do aparente conflito com a garantia da presunção de inocência, e a necessidade de fundamentação no princípio da proporcionalidade, que resguarda a validade de valores constitucionais eventualmente em conflito. No mesmo sentido, revela-se adequada e necessária a observância da cláusula do devido processo legal, resguardado o contraditório e a reação defensiva na formulação e determinação das consequências patrimoniais do ilícito penal.

Palavras-chave: Confisco alargado de bens. Constitucionalidade. Presunção de inocência. Proporcionalidade.

ABSTRACT: The article aims to analyze the compatibility of the institute of the extended confiscation of assets, introduced by Law no. 13,964 / 2019, with the Brazilian Federal Constitution, as an effective instrument for the prevention and repression of organized crime, notably with a focus on its sources of financing. The examination of constitutionality arises from the apparent conflict with the guarantee of the presumption of innocence, and the need to base it on the principle of proportionality, which protects the validity of constitutional values that may conflict. In the same sense, observance of the due process clause is adequate and necessary, safeguarding the adversary and the defensive reaction in the formulation and determination of the 
patrimonial consequences of the criminal offense.

Keywords: Asset extended confiscation. Constitutionality. Presumption of innocence. Proportionality.

SUMÁRIO: Introdução. 1. Regime jurídico da perda de bens no direito brasileiro. 2. Perda alargada de bens e o transplante de compromissos internacionais. 3. Constitucionalidade da perda alargada de bens: presunção de inocência e proporcionalidade. 3.1. Presunção de inocência e confisco alargado: precedentes no direito estrangeiro e no direito internacional dos direitos humanos. 3.2. Do caráter civil do confisco alargado. 3.3. Proporcionalidade. 3.4. A perda alargada de bens na Lei n. 13.964/2019. Conclusão. Referências.

\section{INTRODUÇÃO}

Em dezembro de 2019, foi aprovada a Lei 13964, que dentre outras inovações, alterou o Código Penal, e introduziu o instituto da "perda alargada de bens", com a criação do art. 91-A. ${ }^{1}$

Nesse sentido, o objetivo do artigo é verificar a conformidade do novo instituto com a ordem jurídica constitucional brasileira, em particular a garantia da presunção de inocência, uma vez que a medida, em princípio, atinge o patrimônio lícito do condenado.

A modificação legislativa sob exame, parte do pressuposto de que, em particular nas situações que envolvem a criminalidade organizada, a pena privativa de liberdade tem se mostrado ineficaz na repressão da atividade criminosa. Medidas que asfixiem o financiamento das atividades do crime organizado ganham relevo, pois o lucro obtido com a prática delituosa retorna como fonte de custeio para a continuidade das ações criminosas.

A premissa no estudo da perda ou confisco alargado de bens, é que as medidas cautelares patrimoniais e a perda de bens atualmente vigentes no Código Penal e Processual Penal Brasileiro e legislação extravagante, são insuficientes para a prevenção e repressão aos crimes praticados por organizações ou associações criminosas, notadamente a proteção dos bens jurídicos que são afetados em decorrência dos ilícitos por elas praticados, seja a segurança, a vida, a liberdade, a propriedade, a saúde, dentre outros.

No entanto, o problema da pesquisa consiste na dúvida sobre a constitucionalidade da perda de bens alargada, tendo em vista a aparente violação da garantia da presunção de inocência, em razão da afetação do patrimônio lícito do condenado.

Pretende-se responder, portanto, às seguintes perguntas: a necessidade de proteção de bens jurídicos como vida, liberdade e propriedade, justificam a abrangência da perda dos bens lícitos do condenado, e, portanto, a modulação da presunção de inocência? Se sim, o princípio da

\footnotetext{
1 “Art. 91-A Na hipótese de condenação por infrações às quais a lei comine pena máxima superior a 6 (seis) anos de reclusão, poderá ser decretada a perda, como produto ou proveito do crime, dos bens correspondentes à diferença entre o valor do patrimônio do condenado e aquele que seja compatível com o seu rendimento lícito.

$\S 1^{\circ}$ Para efeito da perda prevista no caput deste artigo, entende-se por patrimônio do condenado todos os bens: I - de sua titularidade, ou em relação aos quais ele tenha o domínio e o benefício direto ou indireto, na data da infração penal ou recebidos posteriormente; e II - transferidos a terceiros a título gratuito ou mediante contraprestação irrisória, a partir do início da atividade criminal.

$\S 2^{\circ} \mathrm{O}$ condenado poderá demonstrar a inexistência da incompatibilidade ou a procedência lícita do patrimônio.

$\S 3^{\circ}$ A perda prevista neste artigo deverá ser requerida expressamente pelo Ministério Público, por ocasião do oferecimento da denúncia, com indicação da diferença apurada.

$\S 4^{\circ} \mathrm{Na}$ sentença condenatória, o juiz deve declarar o valor da diferença apurada e especificar os bens cuja perda for decretada.

$\S 5^{\circ}$ Os instrumentos utilizados para a prática de crimes por organizações criminosas e milícias deverão ser declarados perdidos em favor da União ou do Estado, dependendo da Justiça onde tramita a ação penal, ainda que não ponham em perigo a segurança das pessoas, a moral ou a ordem pública, nem ofereçam sério risco de ser utilizados para o cometimento de novos crimes."
} 
proporcionalidade constitui o método mais adequado para se estabelecer o equilíbrio pretendido? A alteração legislativa verificada atende os parâmetros de proporcionalidade?

O método de análise será o hipotético-dedutivo, a partir da revisão da literatura sobre perda de bens no processo penal, presunção de inocência e princípio da proporcionalidade.

\section{REGIME JURÍDICO DA PERDA DE BENS NO DIREITO BRASILEIRO}

A sentença penal condenatória tem como consequência a aplicação da sanção penal ao agente nela considerado culpado. Todavia, não se pode olvidar que a condenação não tem como único efeito jurídico a aplicação da pena, seja ela privativa de liberdade, restritiva de direitos ou multa. Há também outras consequências jurídicas da condenação penal que podem ser chamadas de acessórias ou secundárias, cuja natureza pode ser penal ou extrapenal (BITTENCOURT, 2015).

Tais efeitos secundários estão previstos no próprio Código Penal, como também na legislação extravagante, e consistem, por exemplo, na obrigação de reparar os danos oriundos da infração penal, na perda de cargo público, função pública, ou mandato eletivo (GRECCO, 2015), ou, ainda, na perda de bens.

Inicialmente cabe destacar, que a Constituição trata nominalmente da perda de bens se referindo a dois institutos diversos. No artigo $5^{\circ}$ da Constituição Federal a perda de bens é ora tratada como pena restritiva de direitos (art. $5^{\circ}$ XLVI, "a", da Constituição Federal) e em outro momento como efeito da condenação penal, ainda que o texto constitucional o faça de maneira indireta ao dispor sobre o princípio da individualização da pena (art. $5^{\circ}, \mathrm{XLV}$, da CF).

A doutrina utiliza tanto o termo "perda de bens" quanto a palavra "confisco" para se referir ao instituto ora analisado ${ }^{2}$ (GRECCO, 2015). Ao passo que no plano internacional, notadamente nas Convenções de Palermo, de Viena e Mérida, preferiu-se a utilização da expressão "confisco".

Com efeito, serão empregadas ambas as expressões, "perda de bens" e "confisco", como sinônimas a fim de designar o objeto deste estudo.

Destaque-se que o tratamento binário não se limita ao campo constitucional, mas também no âmbito infraconstitucional. O Código Penal, por exemplo, trata tanto da perda de bens enquanto pena restritiva de direitos, substitutiva da pena privativa de liberdade (arts. 43 e 44 do CP), como à respeito da perda de bens como efeito da condenação penal (art. 91 do $\mathrm{CP}$ ).

No que diz respeito ao confisco enquanto consequência jurídica, o estatuto repressivo, em conjunto com a legislação especial, previu duas espécies de confisco de bens, a saber: a perda de bens clássica e a perda de bens equivalente ou subsidiária.

A perda de bens clássica, prevista no art. 91, II, "b”, do Código Penal, configura-se medida que retira do patrimônio do condenado quaisquer bens, valores ou proveitos que sejam, direta ou indiretamente, decorrente do crime que ensejou sua condenação em favor da União. ${ }^{3}$

De maneira mais precisa:

produtos do crime (producta sceleris) são as coisas adquiridas diretamente com o crime (ex: coisa roubada), ou mediante sucessiva especificação (ex: joia feita com o ouro roubado), ou conseguidas mediante alienação (dinheiro de venda do objeto roubado) ou criadas com o crime (moeda falsa). Também se inclui no confisco outro qualquer bem ou valor, que importe proveito, desde que haja sido auferido pelo agente, (LYRA, 1942, p. 462-463)

\footnotetext{
${ }^{2}$ Cf: BITTENCOURT (2015, p. 852) e MIRABETE; FRABINI (2015, p. 341)

3 O Art. 91 do Código Penal assim dispõe: "São efeitos da condenação: (...) II - a perda em favor da União, ressalvado o direito do lesado ou de terceiro de boa-fé: a) dos instrumentos do crime, desde que consistam em coisas cujo fabrico, alienação, uso, porte ou detenção constitua fato ilícito; b) do produto do crime ou de qualquer bem ou valor que constitua proveito auferido pelo agente com a prática do fato criminoso".
} 
Em se tratando de meio violento de invasão na esfera individual, a doutrina destaca que é necessário que exista vínculo entre o crime que determinou a condenação e os bens, valores ou proveitos a serem confiscados, embora divirjam quanto à necessidade de fundamentação na sentença quanto a este efeito automático da condenação ${ }^{4}$ (GRECCO, 2015).

Não havendo qualquer diferenciação na lei entre crimes dolosos e culposos no tratamento dado a esta consequência jurídica da condenação, é de se ver que em ambas as modalidades haverá a perda de bens em favor do Estado, embora não seja possível ampliar o conceito de "crime" de maneira que abarque igualmente as contravenções penais (BITTENCOURT, 2015).

Vale mencionar que são resguardados os direitos da vítima ou de terceiros de boa-fé quanto aos bens que se constituam o produto do crime. Um exemplo claro é o direito a restituição da res furtiva que a vítima de um crime de furto tem. Nesse caso, haverá o confisco apenas na hipótese de o produto do crime consistir em quantidade superior aos direitos de terceiros e da vítima, ou o objeto não for reclamado ou ignorado (MIRABETE; FRABRINI, 2015).

Na legislação extravagante, a Lei 9.613/98 (Lei de Lavagem de Dinheiro), também prevê aplicação da perda de bens clássica para os crimes nela tipificados, conforme se depreende da redação do art. $7^{\circ}$, I, do supracitado diploma legal. O detalhe é que a referida lei determina que nos casos cujo processamento e julgamento do crime seja de competência da justiça estadual, a perda será em favor do Estado-membro respectivo, e não da União como indistintamente o Código Penal aborda a questão.

A Lei de Drogas (Lei 11.343/06) também previu o confisco dos bens, valores e proveitos em relação aos crimes nela previstos, que anteriormente tenham sido apreendidos ou sujeitos a medida assecuratória, consoante o seu art. 63, inciso I. Há menção expressa no dispositivo citado, quanto à necessidade de decisão do juiz sobre a decretação do perdimento dos bens na sentença condenatória.

No entanto, a perda de bens clássica, como já apontado, revelava-se insuficiente nas situações em que o agente ocultava o patrimônio obtido com o crime, seja no país ou no exterior. Assim, o legislador, por meio da Lei 12.694/12, acrescentou o parágrafo $1^{\circ}$ no artigo 91 do Código Penal, prevendo a possibilidade de confisco de bens ou valores equivalentes aos auferidos com a prática criminosa. Em outras palavras, esta espécie de confisco, conhecida como perda de bens equivalente ou subsidiária, permite a retirada de bens do patrimônio do agente que não tenham qualquer vínculo, mesmo que indireto, com o crime a qual este foi condenado, substituindo os bens ou valores originários da conduta criminosa que tenham sido ocultados. ${ }^{6}$

Cabe a observação que embora a lei que tenha incluído o confisco dos bens e valores equivalentes, a perda de bens subsidiária não se aplica apenas nessas circunstâncias. Como pontua GRECCO (2015), a espécie de confisco de bens equivalente não se limita apenas às condenações que envolvam as organizações criminosas, mas aos condenados por qualquer crime em que o agente tenha ocultado o patrimônio ilícito.

Insta ressaltar que a inclusão da perda de bens equivalente no ordenamento pátrio é fruto de compromissos assumidos pelo Brasil na esfera internacional no combate à criminalidade. Nesse sentido, a Convenção das Nações Unidas contra o tráfico ilícito de entorpecentes e de substâncias psicotrópicas (Convenção de Viena) prevê adoção pelos Estado- partes da perda de bens subsidiária em seu art. 5', 1, “a”. Do mesmo modo a Convenção de Combate ao Crime Organizado Transnacional (Convenção de Palermo) em seu art. 12, 1, "a", e o art. 31, 1, "a” da Convenção das

\footnotetext{
${ }^{4}$ No mesmo sentido: BITTENCOURT (2015, p.854) e BARROS (2012, p. 280)

${ }^{5}$ Conforme redação dada pela Lei $12.683 / 12$ o art. $7^{\circ}$ da Lei $9613 / 98$ prevê que: "São efeitos da condenação, além dos previstos no Código Penal: I - a perda, em favor da União - e dos Estados, nos casos de competência da Justiça Estadual -, de todos os bens, direitos e valores relacionados, direta ou indiretamente, à prática dos crimes previstos nesta Lei, inclusive aqueles utilizados para prestar a fiança, ressalvado o direito do lesado ou de terceiro de boa-fé”

${ }^{6}$ Art. 91, $\S 1^{\text {o }}$, do Código Penal: "Poderá ser decretada a perda de bens ou valores equivalentes ao produto ou proveito do crime quando estes não forem encontrados ou quando se localizarem no exterior".
}

Revista de Direito Brasileira | Florianópolis, SC | v. 26 | n. 10 | p. 342-364 | Mai./Ago. 2020 
Nações Unidas contra a corrupção (Convenção de Mérida), todas elas devidamente ratificadas e promulgadas no âmbito interno ${ }^{7}$.

Contudo, mesmo com a criação de um tipo penal específico a fim de criminalizar o simples vínculo com as organizações criminosas ${ }^{8}$ - entre outras medidas no campo legislativo - e do incansável trabalho dos órgãos de persecução penal do Estado, é questão pacífica que os atuais instrumentos têm se revelado insuficientes na prevenção da prática delituosa comum, e, principalmente, quando se trata de atividades imputadas às organizações criminosas.

O crime organizado é um fenômeno típico do mundo globalizado, tendo em vista que muitas organizações criminosas não são mais problemas de ordem interna de um determinado Estado, pelo contrário, caracterizam-se pela transnacionalidade das suas atividades e efeitos. $\mathrm{O}$ problema se acentua em razão da penetração político-social e do controle econômico do crime organizado, tornando os mecanismos existentes no sistema nacional de repressão e prevenção ultrapassados (BARROS, 2017).

Como a própria definição legal do conceito de organização criminosas constante no art. $1^{\circ}$ da Lei 12.850/13 permite depreender, é possível visualizá-las como verdadeiras empresas, pois são estruturalmente ordenadas à prática de crimes dirigidas à finalidade de obter vantagens de qualquer natureza 9 . As vantagens, principalmente as de cunho econômico, são fontes de autofinanciamento do crime organizado na manutenção de suas ações. Todavia, num mundo globalizado, por muitas vezes o dinheiro sujo mistura-se com a economia lícita, dificultando a diferenciação do lícito com o ilícito.

Nesse cenário, a adoção de medidas que sufoquem financeiramente tais grupos é de suma importância, sobretudo pela dependência que a criminalidade organizada tem das movimentações de recursos financeiros. Recursos esses em sua maior porção obtidos com crimes anteriormente cometidos por estas organizações, tais como tráfico de drogas, corrupção, lavagem de dinheiro, contrabando, entre outros (PRADO, 2015).

Como mencionado por ESSADO (2014), esses grupos antes de terem suas práticas conhecidas e reprimidas pelo Estado, por certo movimentam muitos recursos que são investidos na continuação delitiva e até mesmo na expansão dela. O raciocínio é simples: um traficante de drogas, por exemplo, normalmente é preso após diversas outras vezes ter sido incurso num dos crimes previstos na Lei de Drogas, lucrando com as suas condutas delitivas e empregando o lucro obtido no custeio da traficância.

\section{PERDA ALARGADA DE BENS E O CUMPRIMENTO DOS COMPROMISSOS INTERNACIONAIS PELO BRASIL}

No âmbito internacional, os esforços na busca de adoção de medidas de maior amplitude patrimonial são crescentes. A partir da interpretação dos art. $5^{\circ}$, item 7 , da Convenção de Viena,

\footnotetext{
${ }^{7}$ A Convenção de Viena, contra o tráfico ilícito de entorpecentes e substâncias psicotrópicas, promulgada pelo Decreto 154, de 26 de junho de 1991 dispõe que: "Art. $5^{\circ}$, item 1. Cada parte adotará as medidas necessárias para autorizar o confisco: a) do produto derivado de delitos estabelecidos no parágrafo 1 do Artigo 3, ou de bens cujo valor seja equivalente ao desse produto". A Convenção de Palermo, contra o crime organizado transnacional, promulgada pelo Decreto 5.015, de 12 de março de 2004, tem dispositivo idêntico, consoante o art. 12, item 1, "a". Semelhantemente, a Convenção de Mérida, contra a corrupção, promulgada pelo Decreto 5.687, de 31 de janeiro de 2006, conforme seu art. 31, item 1, "a".

${ }^{8}$ Nesse sentido a Lei 12.850/13 em seu art. $1^{\circ}$ conceituou organização criminosa como " a associação de 4 (quatro) ou mais pessoas estruturalmente ordenada e caracterizada pela divisão de tarefas, ainda que informalmente, com objetivo de obter, direta ou indiretamente, vantagem de qualquer natureza, mediante a prática de infrações penais cujas penas máximas sejam superiores a 4 (quatro) anos, ou que sejam de caráter transnacional”. Por sua vez, o art. $2^{\circ}$ da referida lei tratou do tipo penal do crime de organização criminosa.

${ }^{9}$ A Convenção de Palermo ao definir o conceito de organização criminosa, em seu art. 2, "a", prescreveu que o seu intuito é a prática de uma ou mais infrações graves a fim de obter, direta ou indiretamente, benefício econômico ou outro benefício material.
} 
do art. 12, II, "a" da Convenção de Palermo, e do art. 31, item 8, da Convenção de Mérida tem se implementado uma nova modalidade de perda de bens cuja extensão do seu objeto é maior, conhecida como confisco alargado ${ }^{10}$.

No mesmo sentido a $\mathrm{OCDE}^{11}$ tem elaborado documentos sobre a necessidade de adoção de medidas de otimização da persecução penal que estanquem o ganho financeiro, inclusive, recomendando o uso do confisco alargado, dado o desarranjo proporcionado pela utilização do patrimônio ilícito no mercado econômico ${ }^{12}$. Mesmo que o enfoque da OCDE seja o combate à corrupção, não se pode esquecer que a corrupção de agentes públicos está umbilicalmente entrelaçada nas atividades das organizações criminosas, que necessitam da cooptação de funcionários públicos para proteção dos negócios ilícitos.

Assim, a preocupação no combate eficaz ao crime vai além da repressão por meio da imposição de penas, pois numa economia globalizada em que cada vez mais os agentes econômicos transitam seus ativos nos mais diversos mercados do globo, a criação de condições que propiciem segurança jurídica, respeito a livre iniciativa e a livre concorrência, valores indispensáveis na criação de uma sociedade justa e próspera, merecem atenção.

O esquema das empreiteiras revelado pela Operação Lava-Jato, as quais pagavam propinas a agentes públicos a fim de fraudarem certames licitatórios e assinarem contratos com a Petrobrás, mostra, por exemplo, que os efeitos da atividade criminosa podem proporcionar graves desarranjos no mercado econômico, desequilibrando o ambiente sadio e competitivo de disputa.

Do mesmo modo, os ganhos obtidos ilicitamente, se introduzidos em circulação, provocam distorções na lógica do mercado, reduzindo os riscos comuns ligados à atividade econômica. Na hipótese do uso de empresas por meio de organizações criminosas, é possível conceber o domínio do mercado, o enfraquecimento da concorrência, o que gerará o aumento do desemprego, e, por fim, o incremento da criminalidade e da violência (LINHARES, 2019).

Assim, no confisco alargado, que consiste na retirada de bens ou valores de pessoa condenada por infração penal que não sejam compatíveis com seus rendimentos de origem lícita, não se busca no patrimônio da pessoa condenada os bens, valores ou vantagens que tenham vínculo com o crime que ensejou a sua condenação, nem o equivalente do produto do crime que eventualmente tenha sido ocultado. O ponto de partida é a identificação do incompatível com os rendimentos demonstrados como lícitos pelo agente condenado em circunstâncias legalmente préestabelecidas, culminando com o confisco da diferença entre o lícito e o presumidamente ilícito (LINHARES; CARDELLI, 2016).

A União Europeia, por meio da Diretiva 2014/42/EU, em seu art. $5^{\circ}$, incentiva seus Estados-Membros a adotarem o confisco alargado de bens, estabelecendo critérios mínimos para a harmonização do direito interno entre os Estados europeus ${ }^{13}$. Contudo, antes mesmo da edição da referida diretiva, vários Estados europeus já haviam adotado a perda de bens alargada cada qual com as suas nuances, entre eles Inglaterra, Portugal e Itália.

\footnotetext{
${ }^{10}$ As Convenções de Palermo e Mérida tem disposições semelhantes nesse sentido. Por outro lado, a Convenção de Viena faculta expressamente a possibilidade de se adotar a inversão do ônus prova: "Art. 5', item 7 . Cada Parte considerará a possibilidade de inverter o ônus da prova com respeito à origem lícita do suposto produto ou outros bens sujeitos a confisco, na medida em que isto seja compatível com os princípios de direito interno e com a natureza de seus procedimentos jurídicos e de outros procedimentos.”.

11 A OCDE (Organização para a Cooperação e Desenvolvimento Económico) é um fórum no qual os governos comparam e trocam experiências políticas, identificam boas práticas à luz dos desafios emergentes e promovem decisões e recomendações para produzir melhores políticas para uma vida melhor do seu povo.

12 ORGANIZAÇÃO PARA A COOPERAÇÃO E DESENVOLVIMENTO ECONÓMICO. Confiscation of instrumentalities and proceeds of corruption crimes in Eastern Europe and Central Asia. Disponível em: https://www.oecd.org/corruption/acn/OECD-Confiscation-of-Proceeds-of-Corruption-Crimes-ENG.pdf. Acesso em: 19 set. 2019.

${ }^{13}$ PARLAMENTO EUROPEU E CONSELHO DA UNIÃO EUROPEIA. Diretiva 2014/42/EU. Disponível em: https://eur-lex.europa.eu/legal-content/PT/TXT/HTML/?uri=CELEX:32014L0042\&from=EN. Acesso em: 20 set. 2019 às 17:01.
}

Revista de Direito Brasileira | Florianópolis, SC | v. 26 | n. 10 | p. 342-364 | Mai./Ago. 2020 
Recentemente, foi promulgada a Lei n. 13964/2019, que dentre outras alterações, introduziu a perda de bens alargada, por meio da inclusão do art. 91-A no Código Penal. Previu-se o confisco alargado como consequência jurídica da condenação. Nos termos do texto aprovado, o pressuposto para aplicação do confisco nessa hipótese é a condenação do agente a um crime apenado com reclusão superior a seis anos. Caberá ao Ministério Público requerer expressamente na denúncia o confisco alargado, apontando neste momento o patrimônio incongruente do acusado. Na hipótese de condenação, ao magistrado na sentença condenatória caberá apontar o patrimônio a ser perdido pelo condenado, sendo previamente oportunizado a este a possibilidade de defesa.

Entretanto, o combate ao crime organizado não pode ser realizado a qualquer custo, muito menos por meio do esvaziamento dos direitos fundamentais dos indivíduos e sem qualquer fundamentação constitucional. A concepção de Estado de Direito impõe limitações ao poder, trazendo garantias aos cidadãos frente a eventuais arbitrariedades quando da invasão do Estado nas suas esferas individuais.

A retirada de ativos que não guardem comprovadamente vínculo com algum ato delituoso traz à tona a discussão a respeito da sua compatibilidade com o princípio da presunção de inocência estampado no art. 5, LVII, da Constituição Federal (SANTOS; SANTOS, 2015). O ponto de tensão é verificar, se a perda de bens alargada, ao privar o agente de bens, valores ou ativos em geral que não sejam fruto de alguma infração penal, implicaria a presunção de responsabilidade penal. Há possibilidade de modulação da presunção de inocência? $O$ princípio da proporcionalidade constitui o caminho mais adequado para essa modulação, por meio da definição de parâmetros, especialmente ante os bens jurídicos que estão em jogo e o dever do Estado em protege-los, cuja inércia pode acarretar uma inconstitucionalidade por omissão?

Tais questões serão objeto de discussão nos próximos tópicos.

\section{CONSTITUCIONALIDAdE DA PERdA ALARGADA DE BENS: PRESUNÇÃO DE INOCÊNCIA E PROPORCIONALIDADE}

Com relação à problemática apresentada por este presente artigo, a sua solução passa, ao menos parcialmente, por identificar no âmbito de proteção da presunção de inocência, seus precedentes históricos e, consequentemente, a sua conformidade com estatutos internacionais.

A identificação de um núcleo essencial, sobretudo comparando com sistemas jurídicos que já admitem o confisco alargado, sem dúvidas fornece subsídio a discussão.

Nesse sentido, a internalização da presunção de inocência na Constituição Brasileira tem dois importantes marcos históricos que são, do ponto de vista internacional, o compromisso na proteção dos Direitos Humanos e, no plano interno, a criação de uma ordem jurídica voltada à proteção do indivíduo.

No plano global, após a Segunda Guerra Mundial, a comunidade internacional percebeu que o meio para impedir o surgimento de novos regimes totalitários, tais como a Alemanha Nazista e a Itália Fascista, seria impedir que as legislações internas de cada Estado permitissem a violação de direitos mínimos dos cidadãos que, por muitas vezes, valendo-se do sistema criminal, fossem utilizados como instrumentos de perseguição política (ZANOIDE, 2010). Assim, buscou-se estabelecer direitos mínimos e universais a todos os seres humanos e a instituição de compromissos que levassem a incorporação deles ao direito interno dos Estado ao redor do globo, para que desse modo fosse possível a convivência pacífica entre as nações (COMPARATO, 2017). Desse movimento surgiria a ONU (Organizações das Nações Unidas).

Evidentemente, o direito à presunção de inocência não surge após a Segunda Grande Guerra. Porém, o esforço global na proteção dos direitos humanos se mostrou relevante na proteção do referido direito pelos mais diversos estados do globo, o que não havia acontecido até então na história. 
O primeiro documento a nível internacional de proteção à presunção de inocência foi a Declaração Universal dos Direitos Humanos. Este relevante documento, que não se limitou a tratar tão somente sobre o direito em comento, estabelece, pela primeira vez, a proteção universal dos direitos humanos.

A previsão da presunção de inocência no aludido documento consta no artigo XI, item 1:

Todo ser humano acusado de um ato delituoso tem o direito de ser presumido inocente até que a sua culpabilidade tenha sido provada de acordo com a lei, em julgamento público no qual the tenham sido asseguradas todas as garantias necessárias à sua defesa.

Não obstante, como fruto do sistema global surgiram também os microssistemas regionais, que intentaram internacionalizar no plano regional a proteção dos direitos humanos, como por exemplo na Europa e América (PIOVESAM, 2018). Outrossim, esses microssistemas elaboraram documentos em que expressamente preveem a presunção de inocência como direito humano a ser protegido.

No continente europeu, a Convenção Europeia de Direitos Humanos, datada de 1950, dispõe sobre a presunção de inocência em seu art. $6^{\circ}$, item 2, dispondo que: "Qualquer pessoa acusada de uma infração presume-se inocente enquanto a sua culpabilidade não tiver sido legalmente provada".

Na mesma Convenção é possível apontar como grande contribuição a criação de órgãos incumbidos de fiscalizar o respeito aos direitos nela declarados e julgar as suas eventuais violações pelos Estados signatários, entre eles a Corte Europeia de Direitos Humanos (COMPARATO, 2017).

A Constituição Portuguesa de 1976, que em seu preâmbulo aduz ser fruto de um processo de libertação do regime fascista, como também a Constituição Italiana de 1948 reproduzem a quebra de regimes totalitários e o movimento internacional de salvaguarda dos direitos humanos (SILVA; JÚNIOR, PEGO, 2018; MIRANDA; MIRANDA, 2014), sendo que ambas conferiram status de direito fundamental à presunção de inocência em seus textos, à semelhante da redação brasileira da Constituição de $1988 .{ }^{14} 15$

No que tange ao microssistema americano, além da formação da Corte Interamericana de Direitos Humanos, foi elaborada a Convenção Americana de Direitos Humanos (Pacto de San José da Costa Rica) que entrou em vigor em 1978, sendo aderido pelo Brasil apenas em 1992. Mesmo tendo sido ratificado pelo Brasil após a promulgação da atual Carta da República, o Pacto de San José da Costa Rica foi inspiração quase que literal do rol de direitos e garantias individuais estampados no art. $5^{\circ}$ da Constituição Federal (ZANOIDE, 2010).

De maneira semelhante a Declaração Universal dos Direitos Humanos e da Convenção Europeia de Direitos Humanos, o Pacto de San José da Costa Rica, demonstrando o alinhamento histórico entre tais documentos, resguardou a proteção da presunção de inocência, como se depreende de seu art. $8^{\circ}$, item 2, que "Toda pessoa acusada de delito tem direito a que se presuma sua inocência enquanto não se comprove legalmente sua culpa”.

Do ponto de vista interno, além do movimento internacional, outro antecedente histórico para que a presunção de inocência recebesse tratamento na ordem constitucional, inclusive como direito fundamental, foi a redemocratização. O período histórico brasileiro anterior, conhecido como regime militar, vigente entre 1964 e 1985, foi marcado por duras medidas perpetradas pelo Estado brasileiro, ao fundamento de se estar se assegurando a ordem vigente ao custo de significativa redução de direitos e garantias individuais. Cidadãos foram submetidos a torturas e,

\footnotetext{
${ }^{14}$ Art. 27 da Constituição Italiana de 1948: "l'imputato non è considerato colpevole sino alla condanna definitiva"

${ }^{15}$ Art. 32 $2^{\circ}$, item 2, da Constituição Portuguesa de 1976: "Todo o arguido se presume inocente até ao trânsito em julgado da sentença de condenação...”
}

Revista de Direito Brasileira | Florianópolis, SC | v. 26 | n. 10 | p. 342-364 | Mai./Ago. 2020 
em alguns casos, sumariamente executados sem qualquer julgamento que respeitasse as concepções de devido processo legal, exercício do contraditório e ampla defesa, noções estas básicas a um processo penal justo (ZANOIDE. 2010).

Maurício Zanoide (2010), em breve síntese, explica os fatores históricos que serviram de sustentáculo histórico a elaboração da Constituição de 1988 e, igualmente, ao tratamento lançado sobre a presunção de não-culpabilidade:

A atual Constituição brasileira foi projetada, elaborada e promulgada no contexto dos anseios de liberdade e redemocratização nacionais e em plena ascensão e consagração internacional da proteção dos direitos humanos.

É de se salientar que, com a Constituição da República Federativa do Brasil de 1988, pela primeira vez a presunção de inocência recebeu tratamento constitucional e, mais do que isso, como direito fundamental na ordem jurídica brasileira. Por certo, essa escolha por parte da assembleia constituinte é uma clara amostra na escolha de um Estado calçado na preservação da dignidade da pessoa humana (ZANOIDE, 2010).

$\mathrm{O}$ reconhecimento da dignidade da pessoa humana, fundamento do Estado Brasileiro, a teor do art. $1^{\circ}$, III, da Constituição Federal, nada mais é que a internalização do objetivo perseguido internacionalmente ao proteger-se os direitos humanos. Assim, é possível visualizar que os diplomas anteriormente mencionados e a Constituição Brasileira não são ilhas isoladas e incomunicáveis.

Notadamente quanto à presunção de inocência, a afirmação supra é verdadeira, pois há claro um alinhamento entre a Constituição Federal, a Declaração Universal dos Direitos Humanos, a Convenção Europeia e a Convenção Interamericana de Direitos Humanos e a Constituição de outros Estados em relação a este direito, sendo possível conceber a existência de núcleo em comum de proteção.

Ademais, impende ressaltar que por mais que terminologicamente se diferencie Direitos Humanos e Direitos Fundamentais, é de se ver que estes representam a introjeção daqueles, por meio de uma constituição, na ordem jurídica interna de um determinado Estado. Contudo, essa internalização não representa nenhuma ruptura no conteúdo dos direitos humanos (SARLET, 2017).

A redação do art $5^{\circ}$, LVII, da Carta Magna, prevê expressamente que: "ninguém será considerado culpado até o trânsito em julgado da sentença penal condenatória”. Nesse ponto, embora a assembleia constituinte tenha lançado mão da fórmula da "presunção de nãoculpabilidade", ao invés da forma "presunção de inocência", como se percebe na redação dos documentos internacionais citados acima, o conteúdo em essência é o mesmo.

Conforme lição doutrinária que diferencia texto normativo e norma, esta é o significado daquela, não se prendendo à sua literalidade, mas sendo o resultado do processo de sua interpretação. Portanto, por mais que a literalidade do texto constitucional apenas assegure o não tratamento como culpado, a norma determina que, ao mesmo tempo, seja considerado inocente (ZANOIDE, 2010).

Independentemente do fato de a Constituição estender a presunção de inocência até o trânsito em julgado da sentença penal condenatória, à semelhança da Constituição Portuguesa, é forçoso concluir que a presunção de inocência é, por um lado, norma probatória ao exigir que a acusação, via de regra exercida pelo Ministério Público, tenha a incumbência do ônus da prova para, além de qualquer dúvida, demonstrar no caso concreto a culpabilidade do agente alvo da persecução criminal. A contrario sensu, não cabe ao acusado provar a sua inocência, tal como monstruosamente aconteceu no regime autoritário do Estado Novo, também conhecido como Ditadura Vargas, consoante o Decreto-lei 88, de 20.12.1937, art. 20, n. 5 (SARLET, 2017). De acordo com o aludido dispositivo legal, presumia-se comprovada a acusação, cabendo ao réu prova 
do não cometimento de crime, sempre que tivesse sido preso com arma na mão, por ocasião de insurreição armada, ou encontrado com instrumento ou documento do crime. ${ }^{16}$

Por outro lado, o direito estudado também é norma de tratamento, pois igualmente impõe ao Poder Público o dever de tratar qualquer suspeito, investigado, indiciado ou acusado por alguma conduta criminosa como inocente, enquanto não declarado culpado por decisão irrecorrível, seja como parte em uma relação jurídica processual ou na esfera extraprocessual (MORAES, 2018). Assim, a autoridade judiciária, a autoridade policial, os agentes carcerários e a administração pública em geral são impedidos de considerar culpado e, por certo, de se comportar de maneira contrária a este entendimento em relação àquele que não fora submetido às condições expostas acima (TAVARES, 2012).

A presunção de inocência é, portanto, um princípio penal que assegura que nenhum indivíduo poderá ser tido por culpado pela prática de qualquer infração penal a não ser após ter sido julgado pelo juiz natural, segundo as normas previamente fixadas de competência, em um procedimento no qual sejam assegurados o contraditório e a ampla defesa, e, posteriormente, condenado. Como consequência lógica, cabe ao Estado, em relação aos suspeitos da prática de crimes ou contravenções penais, acusa-los formalmente e, respeitado o devido processo legal, provar a materialidade e autoria do crime pelo agente (TAVARES, 2012).

\subsection{Presunção de inocência e confisco alargado: precedentes no direito estrangeiro e no direito internacional dos direitos humanos}

Visto que há sintonia entre o sistema brasileiro com os documentos internacionais de proteção aos direitos humanos e outros textos constitucionais, notadamente Portugal e Itália, no que se refere à presunção de inocência, a compreensão do tratamento lançado por esses sistemas em relação ao confisco alargado pode contribuir para as discussões.

A Corte Europeia de Direitos Humanos no julgamento do caso Phillips vs. Reino Unido ${ }^{17}$, cujo objeto era uma ordem de confisco alargado proferida por um tribunal inglês, entendeu não existir nenhuma violação à presunção de inocência, ao fundamento de que este instituto não se caracteriza como sendo de natureza criminal. Na hipótese, o requerente Steven Philips teve decretada contra si uma ordem de confisco no montante de $£ 91.000$ baseada na autorização contida no Drug Trafficking Act 1994, que permitiu a um tribunal inglês supor que todos os bens mantidos pelo requerente, nos seis anos anteriores a condenação, sem comprovação de origem lícita, também representavam serem produto do tráfico de drogas. Conforme foi decidido no julgamento que deu origem ao requerimento a Corte Europeia de Direitos Humanos, o descumprimento no pagamento importaria a conversão da medida de confisco em prisão de dois anos, as quais seriam somadas aos nove anos a que fora inicialmente condenado por ter importado resina de cannabis.

Afastando a alegação de violação ao artigo $6^{\circ}$, item 2, da Convenção Europeia de Direitos Humanos, a Corte entendeu que não ocorreu nova acusação em face de Steven Phillips pela prática de algum outro delito a não ser o que ensejou sua condenação originalmente. No entendimento estampado na decisão, por mais que o Drug Trafficking Act 1994 presuma que o patrimônio do condenado, não meramente acusado, por tráfico de drogas tenha origem em outros delitos semelhantes, não se verificou nenhuma imputação ao indivíduo de nova acusação pela prática de algum crime, mas tão somente a fixação de um critério para a definição da extensão do patrimônio a ser confiscado. No procedimento de confisco, posterior à sua condenação, não houve absolvição e nem mesmo condenação por algum outro crime, tanto que não ocorreu nenhum impacto no seu registro criminal a não ser pela condenação pela importação de resina de cannabis.

\footnotetext{
${ }^{16}$ No Decreto-lei 88, de 20.12.1937, art. 20, n. 5, expressamente constava que: "Presume-se provada a acusação, cabendo ao réu prova em contrário, sempre que tenha sido preso com arma na mão, por ocasião de insurreição armada, ou encontrado com instrumento ou documento do crime"

${ }^{17}$ EUROPEAN COURT OF HUMAN RIGHTS. Phillips v. The United Kingdom - Application no. 41087/98
} Revista de Direito Brasileira | Florianópolis, SC | v. 26 | n. 10 | p. 342-364 | Mai./Ago. 2020 
A Corte Europeia de Direitos Humanos observou que mesmo que a presunção de inocência se aplique em relação a todo o processo penal e não apenas em relação à análise do mérito da acusação, incluindo também o procedimento de confisco após a condenação, o direito de presumir-se inocente nos termos previstos na Convenção surge apenas em conexão com a acusação de uma infração específica. Tendo sido devidamente comprovada a culpa do réu, a presunção de inocência não seria aplicável em relação às alegações feitas sobre o caráter e a conduta do acusado no tocante ao procedimento de confisco, a menos que tais acusações sejam de natureza e grau que sejam equivalentes a uma nova acusação.

No caso Butler vs. Reino Unido ${ }^{18}$, também houve um requerimento levado à Corte numa situação referente a uma ordem confisco de bens não relacionados a uma condenação por tráfico de drogas, mas que poderiam ser fruto da atividade delitiva ou usados em proveito dela. Segundo o requerente, Francis John Butler, o procedimento de confisco tem natureza criminal, razão pela qual deveria atrair as garantias do processo criminal, sobretudo o direito à presunção de inocência. Contudo, esse não foi o entendimento da Corte, a qual concluiu que a ordem de confisco era uma medida preventiva e não poderia ser caracterizada com uma sanção penal propriamente dita, uma vez que foi projetada para tirar de circulação o dinheiro que se presume estar vinculado com o comércio internacional de drogas ilícitas. De maneira similar ao caso Phillips, concluiu-se pela impossibilidade do caso resultar em uma nova condenação, não maculando o registro criminal do requerente, ante a ausência de nova acusação pela prática de algum crime.

Cabe pontuar que a Corte Europeia de Direitos Humanos já teve em mais de uma oportunidade a possibilidade de analisar o confisco preventivo antimáfia italiano, entendendo-a como medida não criminal (SIMONATO, 2017). Essa modalidade preventiva embora não se confunda com a confisca allargata, é vista como análoga a ela, diferenciando-se apenas no momento da aplicação. No confisco preventivo a restrição do patrimônio pode ocorrer bastando apenas fundada suspeita, mesmo que não haja responsabilização penal anterior, enquanto no confisco alargado ela ocorre em momento posterior à condenação criminal (BEZERRA, 2019).

Essencialmente, analisando do ponto de vista do confisco preventivo, a Corte Europeia de Direitos Humanos não caracteriza como sendo de natureza criminal o confisco de bens que não guardem relação com algum crime em que o agente tenha sido eventualmente condenado anteriormente. Esses casos levados à Corte dizem respeito a ordens de confisco em circunstâncias que o agente sequer tenha sido processado criminalmente, tendo ocorrido a perda de bens por meio de um procedimento civil, entendendo a Corte que a referida retirada do patrimônio ante o seu caráter preventivo não tem natureza criminal (SIMONATO, 2017).

Na Itália, a jurisprudência do país tem entendido que a confisca allargata tem natureza de medida de segurança atípica, o que afastaria eventual ofensa à presunção de inocência, havendo críticas a esse posicionamento (MILONE, 2018). Nesse cenário, não se busca a comprovação da culpabilidade do agente, mas a caracterização da sua periculosidade como fundamento para a ordenar a perda alargada de seus bens ante o perigo do patrimônio incongruente deixado em livre disponibilidade nas mãos de sujeitos condenados por crimes graves ser utilizado em novas práticas criminosas ${ }^{19}$ (CORTESI, 2014).

Em Portugal, embora existam aqueles que também defendam a natureza de medida de segurança do confisco alargado (CUNHA, 2014), o Tribunal Constitucional e parcela da doutrina tem apontado, de modo diverso, que a modalidade de confisco em estudo tem natureza civil em razão do seu caráter preventivo. O Tribunal pontua que não se busca responsabilizar criminalmente o agente que tem o seu patrimônio retirado, mas impedir que o patrimônio presumidamente ilícito, sem que o agente tenha obtido êxito em afastar tal presunção, seja realocado em novas práticas criminosas $^{20}$.

\footnotetext{
${ }^{18}$ EUROPEAN COURT OF HUMAN RIGHTS. Butler v. United Kingdom - Application no. 41661/98

${ }^{19}$ Cass., Sez. V, 16 maggio 2014 (dep. 22 luglio 2014), n. 32353, Pres. Dubolino, Rel. Guardiano, Imp. G.M.

${ }^{20}$ TRIBUNAL CONSTITUCIONAL DE PORTUGAL. Acórdão 392/2015.
} 


\subsection{Do caráter civil do confisco alargado}

Tem-se que a definição da natureza do confisco tem grande relevância na identificação dos direitos fundamentais que podem ser eventualmente ofendidos. Em outras palavras, o caminho que se propõe a seguir na identificação sobre a natureza do confisco, civil ou penal, não tem o escopo de ser puramente acadêmico, pelo contrário, implicará a definição do regime jurídico aplicável, a permitir a superação ou não das questões ora suscitadas (CORREIA, 2012; MORO, 2010).

Afasta-se de logo a noção de que o confisco tenha eventualmente natureza administrativa, ao menos nos termos aqui discutidos, por não se verificar uma relação jurídica no âmbito de tutela do Direito Administrativo. Neste ramo do direito são disciplinadas as relações da Administração Pública entre si ou da Administração Pública com particulares, o que não é o caso.

Ato contínuo, no Brasil, como pontua ESSADO (2014), os autores não tecem grandes fundamentações a fim de justificar a escolha da natureza do confisco, seja ela civil ou penal. Basicamente, aqueles que optam pela natureza penal do confisco justificam seu posicionamento em razão do instituto ter previsão na lei penal e ser aplicado durante um processo penal. Por outra via, é possível justificar a opção pela natureza civil do confisco, a despeito da previsão do confisco no Direito Penal, tendo em vista que a sua aplicação não leva em conta critérios relacionados a culpabilidade, objetivando-se apenas desconstituir uma situação de enriquecimento ilícito ou de uma situação patrimonial ilícita.

A previsão do confisco na lei penal e sua aplicação pelo juízo penal não têm o condão de justificar que este assuma natureza penal, pois outros institutos também encontram previsão em legislações materialmente penais e igualmente são aplicadas no transcorrer do processo penal e nem por isso exibem tal natureza, como é o caso da obrigação de indenizar o dano e da perda do poder familiar. Do mesmo modo, também a afastar a natureza penal do confisco, o art. $5^{\circ}, \mathrm{XLV}$, da Constituição Federal, que versa sobre o princípio da responsabilidade pessoal do agente criminoso ou princípio da intranscendência, expressamente dispõe que a perda de bens e a obrigação de reparar o dano, pelo o que se verifica a semelhança dos dois institutos, poderão ser transferidas aos sucessores do agente criminoso eventualmente falecido, em opção do constituinte em conferir tratamento civil ao confisco (VIEIRA, 2017).

Em outros termos, o legislador constituinte determinou ser inadmissível a transferência da responsabilidade criminal do agente para outrem, sobretudo os efeitos de natureza penal da condenação. Porém, quando do tratamento do confisco, o fez de maneira idêntica da reparação do dano, que é um efeito de natureza civil. Assim, é forçoso concluir que o confisco na ótica constitucional brasileira tem natureza semelhante à obrigação de reparar o dano causado pela infração penal, isto é, natureza civil.

No que tange ao confisco alargado, é possível igualmente visualizar que este é de natureza civil, pois não se trata de condenação penal pela prática de crimes hipotéticos, que não foram previamente demonstrados, tão somente uma medida aplicável a uma situação patrimonial inexplicável. Busca-se impedir a manutenção e a consolidação do patrimônio incongruente, suspeito de proveniência ilícita, que possivelmente será utilizado no financiamento de atividades ilícitas de um agente que, ao que tudo indica, teria um estilo de vida criminoso, ainda mais na hipótese de estar vinculado a uma organização criminosa.

Não se identifica o confisco alargado com uma sanção penal, seja por não se elaborar qualquer juízo sobre a tipicidade da conduta ou da culpabilidade do condenado em relação ao período utilizado para o acertamento patrimonial, seja por significar simplesmente um retorno ao status quo anterior, ou uma vedação ao enriquecimento ilícito ou sem causa. A única condenação tipicamente penal relacionada ao confisco alargado serve, tão somente, para deflagrar o procedimento patrimonial, na implementação do confisco em si (VIEIRA, 2017). 
Sob a ótica civil, perfeitamente possível identificar que o instituto detém finalidade reparatória $^{2122}$ e preventiva.

No tocante ao procedimento, ao menos no modelo ora defendido, ainda sem se analisar a previsão específica do art. 91-A do Código Penal, é de se ver que a discussão deve girar em torno apenas do aspecto patrimonial. ${ }^{23}$

O escopo do procedimento é puramente objetivo, vale dizer, identificar o patrimônio desproporcional com o rendimento lícito do agente. Assim, como a culpa se revela como um aspecto subjetivo, que deverá estar previamente acertada, permanecerá ela intacta, não havendo qualquer alteração do status jurídico do condenado (ESSADO, 2014).

Sob essa perspectiva, o standard of proof ${ }^{24}$ não precisará ser o mesmo que o necessário para a formação do juízo de culpa do acusado como ocorre por força do princípio da presunção de inocência no processo crime, vale dizer, um standard de prova acima de qualquer dúvida razoável. Não se buscando responsabilizar o agente criminalmente o critério da prova poderá se aproximar daquele exigido pelo processo civil baseado na preponderância de provas.

No modelo ora proposto, para além da criação de um catálogo de crimes cuja condenação autorizaria a aplicação da perda alargada de bens, devem existir elementos probatórios que indiquem conduta criminosa habitual, reiterada ou profissional do condenado ou a sua vinculação a organização criminosa. Tudo para que o instituto não fique descaracterizado e perca a finalidade para qual foi pensado.

Destaque-se que a demonstração da atividade criminosa habitual, reiterada ou profissional ou a membresia em organização criminosa poderia ocorrer no procedimento autônomo sem a necessidade de discutir-se a culpabilidade do agente nessa fase, desde que na hipótese o confiscado tenha sido condenado pelo crime de organização criminosa, ostente maus antecedentes ou reincidência, de acordo com parâmetros legais. Assim, os elementos seriam satisfeitos de forma objetiva, motivo pelo qual o procedimento da perda de bens restaria a discutir tão somente o patrimônio incongruente.

Portanto, concluindo pela natureza civil ou não penal, do confisco, até mesmo na sua modalidade alargada como em outros ordenamentos, é possível concluir que este não se insere no âmbito de proteção da presunção de inocência, pois não feitas novas acusações ao agente e muitos menos se busca responsabiliza-lo criminalmente por outros crimes, mas tão somente identificar o patrimônio em situação contrária ao direito. A restrição patrimonial se dará após a fixação da culpabilidade, por meio de um procedimento que não deverá tratar sobre aspectos de culpabilidade, respeitado o devido processo legal e os direitos à ampla defesa e ao contraditório, sendo possível ao agente demonstrar a origem lícita de seus bens de forma a impedir eventual ordem de confisco.

Isto posto, afastada a aparente contradição da perda de bens alargada com outros direitos fundamentais, em especial o direito à propriedade, resta examinar, à luz da proporcionalidade,

\footnotetext{
${ }^{21}$ Antônio Scarance Fernandes sustenta a possibilidade de se falar em vítimas coletivas ou difusas quando a norma penal proteja bens jurídicos coletivos ou difusos (1995, p. 235). Sérgio Fernando Moro exemplifica a situação citando o acréscimo patrimonial que o agente aufere com um crime de tráfico de entorpecentes que teria como contrapartida o consumo "das riquezas da sociedade", despendidas "a fim de remediar os danos à saúde pública e aos indivíduos atingidos pelo consumo de drogas" (2010, p. 169).

${ }^{22}$ Com posicionamento contrário, Olavo Evangelista Pezzoti aduz não ser possível a reparação dos danos oriundos da criminalidade difusa pela impossibilidade de quantificar os prejuízos suportados pela sociedade, bem como pela destinação não necessariamente vinculada a reparar diretamente os danos (2019, p. 65).

${ }^{23}$ Nos termos da proposta haveria a inclusão do art. 91-A, $\S 3^{\circ}$, nos seguintes termos: “Após o trânsito em julgado, o cumprimento do capítulo da sentença referente à perda de bens, direitos e valores com base neste artigo será processado no prazo de até dois anos, no juízo criminal que a proferiu, nos termos da legislação processual civil, mediante requerimento fundamentado do Ministério Público que demonstre que o condenado detém, nos termos do $\S 1^{\circ}$, patrimônio de valor incompatível com seus rendimentos lícitos ou cuja fonte legítima não seja conhecida."

${ }^{24}$ PEZZOTTI explica standard of proof como: "modelos (ou critérios) de controle do juízo podem ser definidos como enunciações teóricas capazes de ensejar o controle da convicção judicial objeto de uma determinada decisão e que expressam uma gradação, quantitativa e qualitativa, exigível para a formação do convencimento judicial" $(2019,82)$
}

Revista de Direito Brasileira | Florianópolis, SC | v. 26 | n. 10 | p. 342-364 | Mai./Ago. 2020 
quais os parâmetros que devem ser respeitados para resguardar a constitucionalidade e legitimidade da medida.

\subsection{Proporcionalidade}

Preambularmente, é de se reconhecer em relação ao objeto do presente estudo a colisão entre princípios, valores e direitos fundamentais. De um lado, temos o princípio constitucional da presunção de inocência como principal impeditivo, em tese, a perda bens alargada, e, por outro lado, os valores constitucionais como a segurança, a vida, a liberdade, a propriedade, a saúde, dentre outros, que corroboram com a sua adoção.

Nesse cenário, é necessário identificar caminhos interpretativos que permitam solucionar o aparente conflito entre os valores constitucionais mencionados. Como não se está diante de um conflito de regras, não se aplicam no presente caso os clássicos critérios de cronologia, hierarquia e especialidade para a solução de uma antinomia. Na verdade, tais critérios se revelam inócuos tendo em vista que em se tratando de princípios, valores ou direitos fundamentais, os tais se encontram positivados no texto constitucional e, portanto, se encontram no mesmo patamar hierárquico e representam o âmago do Estado "criado" com a Constituição vigente.

Enquanto na solução dos conflitos de regras, também conhecida como antinomia, aplicase tão somente uma das normas colidentes, negando-se vigência as demais. Por sua vez, na hipótese de conflito entre normas de índole constitucional, explícitas ou implícitas, assim como no presente caso, devem elas coexistir, sendo inadmissível que na solução da colisão concretamente considerada uma norma suprima outra norma, sob pena de negar a vigência que o texto constitucional exerce sobre todo o ordenamento jurídico.

A modulação da colisão das normas constitucionais passa pela proporcionalidade. A proporcionalidade não é apenas mero critério para a solução do aparente conflito de normas constitucionais, pois, apesar de não expressamente previsto na Constituição Federal de 1988, é pacífico que a proporcionalidade é princípio constitucional implícito, derivado do conceito material do devido processo legal (BARROSO, 2013). Ao mesmo tempo é pressuposto do Estado Democrático de Direito, sendo que sua função é hierarquizar todos os demais princípios a partir de situações em concreto, de modo a conferir a "unidade e consistência" almejadas no ordenamento (GUERRA FILHO, 2001).

Esse importante princípio assume duas facetas que servem como norte na sua compreensão e contribuem para solução da discussão posta, qual seja a proibição do excesso e a vedação da proteção deficiente. Nesse sentido, tendo em vista ser exigido que o Estado venha a agir a fim de proteger os bens jurídicos de tratamento constitucional, sua atividade não pode arbitrariamente, sem qualquer parâmetro, os suprimir, o que caracterizaria a proibição do excesso (Übermass). No entanto, o princípio da proporcionalidade atribui ao Poder Público o dever de agir de forma positiva, evitando-se que, por omissão, deixe de dar a devida concretude aos bens jurídicos constitucionais, impondo sob outro prisma a vedação da proteção insuficiente (Übermassverbot).

No tocante à proibição da proteção deficiente, é de se mencionar a doutrina da eficácia horizontal dos direitos fundamentais, fruto de uma conclusão básica: a de que direitos fundamentais também são violados por particulares, e não apenas pelo Estado. Em se tratando do direito penal, a conclusão supra é verdadeira pois é exatamente nesse ramo do direito que se tem uma pessoa física violando o direito fundamental de outra, o que torna exigível a atuação estatal (STRECK, 1999).

Isto posto, o postulado da proporcionalidade serve como regra de interpretação constitucional e método racional de ponderação dos bens jurídicos constitucionais em conflito. Esse balanceamento proporcional de bens jurídicos se calca em três elementos, conforme leciona Konrad Hesse (2009). De acordo com o citado jurista alemão, mencionando as decisões do Tribunal 
Constitucional Alemão, a limitação dos direitos fundamentais deve ser adequada à obtenção do objetivo público a ser perseguido (adequação). Tem que ser evidenciado no caso concreto que o meio se mostrar necessário (necessidade), a partir da inexistência de outro meio igualmente eficaz que não afete ou o faça de maneira sensivelmente menor ao direito fundamental. Por último, conjugando a envergadura da intervenção e a imperiosidade dos motivos justificantes, há mais vantagens do que desvantagens na limitação do direito fundamental em espécie (proporcionalidade em sentido estrito).

Saliente-se que qualquer previsão legal que importe em uma restrição a um bem jurídico constitucional, sobretudo a um direito fundamental, deve preservar o núcleo essencial do direito comprimido (ANDRADE, 1976), sob pena de se revelar desproporcional e, consequentemente, inconstitucional.

Como assinalado, a presunção de inocência tem sido o cerne da discussão quanto a implementação do alargamento do objeto da perda de bens. Desse modo, a compreensão de qual seja a essência do aludido preceito fundamental, portanto, permitirá concluir pela proporcionalidade ou não da introdução da perda de bens alargada na ordem jurídica brasileira, mormente se comparado juntamente com outros valores de índole constitucional.

Nos tópicos antecedentes o núcleo essencial da presunção de inocência foi devidamente apreciado, bem como o tratamento da perda de bens alargada em outros ordenamentos jurídicos à luz do direito fundamental em comento. Resta-nos, portanto, compreender se é possível, à luz do exposto, modular o conflito da presunção de inocência, respeitando seu núcleo essencial, e os demais valores constitucionais em tensão.

Tome-se como ponto de partida o direito fundamental à propriedade, previsto no art. $5^{\circ}$, XXII, da Constituição Federal. Assim como qualquer direito fundamental, a propriedade não é absoluta, como se fora possível ser exercida sem limitações. A conclusão supra se dá em razão dos contornos dados à propriedade pelo próprio texto constitucional. Nesse sentido, no inciso XXIII do mesmo art. $5^{\circ}$ da Carta Magna a norma constitucional dispõe que a propriedade será exercida de acordo com a sua função social. ${ }^{25}$

A função social confere ao direito à propriedade um caráter finalístico, não mais voltado apenas ao indivíduo que é o proprietário, mas atento à proteção dos interesses e das necessidades da coletividade. Essa finalidade não se constitui mera limitação ao direito, mas compõe o seu conteúdo essencial, de forma que direito à propriedade e a função social estão interligados (TARTUCE, 2018).

Cabe pontuar que a função social não se confunde com o aproveitamento econômico da propriedade. É possível que exista o último e ao mesmo tempo ocorra ofensa à função social da propriedade (LÔBO, 2015). Essa diferença é identificável na hipótese de utilização da propriedade para o cultivo de psicotrópicos ou a exploração de trabalho escravo, que apesar do aproveitamento econômico evidente representa violação ao núcleo do direito à propriedade, tanto que a Constituição Federal admite a desapropriação confisco nessas hipóteses. ${ }^{26}$

No que se refere ao confisco alargado, visto ser caracterizado como de natureza civil e sob essa ótica consiste em medida reparatória e preventiva, não se constata a desproporcionalidade da sua inserção, sobretudo à luz da função social da propriedade, que, pelo contrário, o legitima.

\footnotetext{
${ }^{25}$ A Constituição Federal ao versar sobre o direito à propriedade enquanto direito fundamental: "Art.5. XXII - é garantido o direito de propriedade; XXIII - a propriedade atenderá a sua função social”.

${ }^{26}$ Nesse sentido a Constituição Federal: “Art. 243. As propriedades rurais e urbanas de qualquer região do País onde forem localizadas culturas ilegais de plantas psicotrópicas ou a exploração de trabalho escravo na forma da lei serão expropriadas e destinadas à reforma agrária e a programas de habitação popular, sem qualquer indenização ao proprietário e sem prejuízo de outras sanções previstas em lei, observado, no que couber, o disposto no art. $5^{\circ}$. (Redação dada pela Emenda Constitucional no 81, de 2014) Parágrafo único. Todo e qualquer bem de valor econômico apreendido em decorrência do tráfico ilícito de entorpecentes e drogas afins e da exploração de trabalho escravo será confiscado e reverterá a fundo especial com destinação específica, na forma da lei”
} 
Como destaca ESSADO (2014) o atendimento à função social a partir do estudo sistemático da Constituição pressupõe que o direito de propriedade seja legítimo, vale dizer, tenha origem lícita. Sendo assim, na perspectiva reparatória a perda de bens alargada ao buscar desconstituir uma situação patrimonial ilícita, que deverá ser confirmada após um procedimento específico para apuração deste fato, que visa garantir o conteúdo essencial do direito à propriedade em sua finalidade coletiva, afastando a manutenção da propriedade de origem ilícita pelo agente, bem como reparando os danos à coletividade. Nesse raciocínio, é manifesto não ser do interesse da coletividade que um indivíduo construa seu patrimônio por meio ilícito, ainda mais na hipótese de auferir lucro causando prejuízos difusos.

Com efeito, não pode ser configurado como de origem lícita e, consequentemente, que atenda à sua finalidade social a propriedade que seja decorrente de condutas que anteriormente tenham causado danos a sociedade, mesmo que difusos.

Por outro lado, a função social apesar de ter como pressuposto a origem lícita, funda-se especialmente na finalidade do uso da propriedade, que certamente não poderá ser ilícita. Tanto que o legislador constituinte, como já mencionado, tratou expressamente de hipóteses de confisco em situações do uso ilícito da propriedade, consoante a previsão contida no artigo 243 da Constituição Federal.

Relativamente ao confisco de glebas em que haja o cultivo de psicotrópicos, o Supremo Tribunal Federal no julgamento do Recurso Extraordinário 543.974/ $\mathrm{MG}^{27}$ entendeu que a perda da propriedade não se limitava à porção em que ocorreu o plantio, porém se estendia a toda a propriedade, incidindo sobre a parcela do bem não utilizada para o fim ilícito. Conforme o voto do ex-ministro César Peluso, a medida confiscatória na hipótese representava uma sanção grave exatamente pelo alto desvalor jurídico do ato praticado e que a limitação apenas a porção em que teria sido efetuado o cultivo poderia levar a absurda situação em que o remanescente do bem poderia continuar sendo utilizado para o fim criminoso, sendo que o objetivo da norma seria o desincentivo a prática da conduta.

Aplicando-se a mesma lógica ao confisco alargado, em sua ótica preventiva, a retirada de patrimônio tem como objetivo afastar o lucro auferido com atividades ilícitas, desestimulando o indivíduo à prática de novas infrações penais, bem como inibir que terceiros seduzidos pelas vantagens econômicas também iniciem na carreira criminosa. No âmbito do crime organizado, a retirada do patrimônio incongruente do agente tem o condão de impedir o seu uso no financiamento de novas práticas delitivas.

A função social da propriedade também é princípio da ordem econômica, nos termos do art. 170 do texto constitucional ${ }^{28}$. Para além da função social da propriedade, a ordem econômica também tem entre os seus princípios a livre concorrência e a busca do pleno emprego, aspirando conferir a todos uma existência digna.

Repise-se que em muitas situações organizações criminosas cooptam agentes públicos afim de imporem sua agenda econômica. Em um esquema de corrupção, por exemplo, os valores desviados causam vultuosos desfalques no erário - obstaculizando a consecução do interesse público -, concorrem para o aumento injustificado da inflação, e desequilibram o ambiente de livre concorrência, destruindo empresas que não aderem ao esquema de corrupção, aumentando o desemprego e proporcionando o crescimento da violência urbana.

\footnotetext{
${ }^{27}$ SUPREMO TRIBUNAL FEDERAL. RE 543.974/MG, rel. Eros Grau, data de julgamento: 25/03/2009.

28 Art. 170 da Constituição Federal: “ A ordem econômica, fundada na valorização do trabalho humano e na livre iniciativa, tem por fim assegurar a todos existência digna, conforme os ditames da justiça social, observados os seguintes princípios: I - soberania nacional; II - propriedade privada; III - função social da propriedade; IV - livre concorrência; V - defesa do consumidor; VI - defesa do meio ambiente, inclusive mediante tratamento diferenciado conforme o impacto ambiental dos produtos e serviços e de seus processos de elaboração e prestação; VII - redução das desigualdades regionais e sociais; VIII - busca do pleno emprego; IX - tratamento favorecido para as empresas de pequeno porte constituídas sob as leis brasileiras e que tenham sua sede e administração no País.
}

Revista de Direito Brasileira | Florianópolis, SC | v. 26 | n. 10 | p. 342-364 | Mai./Ago. 2020 
Também é comum o uso por organizações criminosas de sociedades empresárias para prática continuada de lavagem de capitais, igualmente causando impactos sensíveis sob a perspectiva macroeconômica, notadamente afetando a livre concorrência. A distorção ocorre pela mistura do dinheiro lícito com o dinheiro "sujo", pelo o que os riscos comuns da atividade econômica restam anulados, afetando a lógica da economia de mercado, possibilitando a predação da concorrência. Em outras palavras, a mescla entre o patrimônio lícito com o ilícito nas atividades econômicas possibilitam aos agentes auferir ao menos três benefícios, a saber: a perspectiva superior de lucros com a atividade desenvolvida, especialmente em longo prazo, mediante consolidação no mercado regular, cumulada com a eliminação de riscos e, por último, confere aparência de licitude ao patrimônio ilícito (PEZZOTI, 2019).

Nos dois cenários exemplificativos apontados acima, além do desvio da função social da propriedade, verificável a partir da análise da origem do patrimônio do infrator, como também com a distorção na ordem econômica, há clara violação ao ambiente sadio de livre concorrência, à moralidade pública, implicando no aumento do desemprego e trazendo efeitos negativos no âmbito da segurança pública.

A própria Constituição Federal confere tratamento constitucional à segurança pública, atribuindo sua responsabilidade ao Estado $^{29}$. Dessa maneira, o Poder Público deve canalizar esforços não apenas a dar a devida proteção a esse bem jurídico, como aos demais supracitados, ainda que se trate de agressão perpetrada por particulares, sob pena de violar a Constituição por omissão.

Afora que os crimes econômicos comprometem a ordem pública, a justiça social, o desenvolvimento econômico, a liberdade de iniciativa, a expansão das oportunidades, a soberania nacional, e o favorecimento dos direitos do trabalhador (BASSO, 2015).

Nesse contexto, o controle da proporcionalidade é expressão do controle de constitucionalidade, na medida que proporciona a compatibilização do direito formal com o direito material no sentido de atender as exigências das transformações sociais, incontroláveis do ponto de vista do positivismo jurídico caso não houvesse a funcionalidade do princípio em questão, caracterizado como "novo axioma constitucional" (GUERRA FILHO, 2001). Isso permite que a Constituição vigente se amolde a realidade social atual, especialmente passados 30 anos da promulgação do texto constitucional, notadamente após o crescimento da criminalidade organizada e a consolidação da criminalidade econômica, circunstâncias estranhas ao legislador constituinte.

Portanto, se o núcleo essencial do direito a presunção de inocência nas circunstâncias expostas permanece íntegro visto que não existe nenhuma acusação do ponto de vista formal, sem qualquer efeito jurídico próprio de uma condenação, mormente quando é imposto ao Estado intervir a fim de dar concretude aos valores, direitos e princípios constitucionais, o perdimento de bens alargado se revela medida proporcional, ao menos em tese.

Todavia, o perfeito atendimento à proporcionalidade requer análise da perda de bens alargada concretamente positivada por meio da Lei n. 13.964/2019, haja vista as nuances que o legislador brasileiro prescreveu em comparação com modelos estrangeiros.

\subsection{A perda alargada de bens na Lei n. 13.964/2019 e os parâmetros de proporcionalidade}

Não obstante o posicionamento favorável à implantação do confisco alargado, é de se reconhecer que a modificação, introduzida pela Lei n. 13.964/2020, traz alguns pontos de atenção em relação ao atendimento do princípio da proporcionalidade.

Em primeiro lugar, não há um rol taxativo de crimes que admitiriam a ordem de confisco, limitando-se o novo dispositivo a exigir a condenação a pena superior a 6 (seis) anos de reclusão,

\footnotetext{
${ }^{29}$ Nesse sentido é a previsão do Art. 144 da Constituição Federal: “A segurança pública, dever do Estado, direito e responsabilidade de todos, é exercida para a preservação da ordem pública e da incolumidade das pessoas e do patrimônio, através dos seguintes órgãos"
}

Revista de Direito Brasileira | Florianópolis, SC | v. 26 | n. 10 | p. 342-364 | Mai./Ago. 2020 
pouco importando a natureza da infração penal. Não se exige, ainda, a demonstração de elementos que comprovem a habitualidade ou profissionalidade delitiva ou vínculo com alguma organização criminosa. Vale dizer, mesmo que o réu seja primário, com bons antecedentes, ausente qualquer informação a respeito da reiteração delitiva, condenado por um crime sem finalidade econômica, haverá possibilidade, em tese, de confisco.

O novo art. 91-A do Código Penal também não indica um limite temporal sobre o qual poderá recair a ordem de confisco, diferentemente de outros países. Até mesmo os bens recebidos posteriormente à data da infração penal poderão, em tese, ser declarados perdidos. O que significa que o patrimônio do agente poderá ser alcançado ad eternum. A indicação de um limite temporal é uma exigência de proporcionalidade, para evitar que se expropriem bens que não tenham vínculos com outras investidas criminosas não correlatas à condenação do confiscado, por exemplo, a perda de bens adquiridos 20 (vinte) anos antes. Até mesmo a possibilidade de se produzir prova da origem lícita dos bens poderá se tornar impossível após tanto tempo, ainda mais diante do cenário de informalidade do mercado negocial brasileiro, e nesse caso o risco de presunção de culpa, e, portanto, de violação da presunção de inocência, é inevitável.

É bem verdade que ainda que o texto não traga a limitação temporal desejada, é evidente que caberá à acusação o ônus de demonstrar a relação de vínculo entre patrimônio e ato ilícito, sob pena de ilegalidade da medida. No entanto, como a prática forense mostra que até mesmo o ônus da prova para a condenação do acusado é relativizado, preocupa como a acusação se desincumbirá do seu ônus no que tange à perda alargada.

Esses pontos supramencionados podem descaracterizar o propósito do instituto da perda alargada assim como fora pensado, em razão do aumento do poder e da discricionariedade dos órgãos de persecução penal do Estado. Os apontamentos devem ser cuidadosamente discutidos, pois no Brasil muitas vezes o mercado negocial é caracterizado pela informalidade, inclusive na transferência de bens móveis e imóveis (SANTOS; SANTOS, 2015). É preciso ter prudência para que a invasão na esfera individual ocorra em circunstâncias em que o estilo de vida delitivo do confiscado seja evidenciado.

Detalhe importante, é que caberá ao Ministério Público, por ocasião do oferecimento da denúncia, apontar o patrimônio incongruente. Se de um lado faz sentido que essa exigência visa atender o contraditório e o direito de defesa, por outro lado faz igualmente sentido reconhecer, o necessário esforço probatório prévio a permitir que esse apontamento seja feito logo na denúncia. Caso contrário, a medida não poderá ser decretada na sentença, e deverá ser objeto de demanda própria na esfera cível.

A discussão sobre o confisco correrá de forma simultânea à ação penal, tanto que o ao sentenciar o feito o juiz deverá determinar a perda de bens alargada após ter sido exposto a informações que poderão influenciar na sua convicção a respeito da culpabilidade do agente, mesmo que essas não guardem relação aos fatos apreciados no processo-crime. Esse ponto demonstra a contradição da Lei n. 13.964/2019, pois a um só tempo implementou o denominado Juiz das Garantias a fim de resguardar a imparcialidade do Juiz sentenciante e, ao mesmo tempo, permitiu que imparcialidade deste fosse maculada ao ser expostos a informações que no íntimo podem fazê-lo pender para um lado.

\section{CONCLUSÃO}

O presente artigo buscou responder às seguintes perguntas: o confisco alargado de bens no processo penal, é compatível com o princípio da presunção de inocência? O princípio da proporcionalidade constitui o método idôneo a parametrizar a sua aplicação?

A partir dos argumentos e fundamentos expostos, a resposta é afirmativa para ambas as questões. 
Mesmo diante da tensão entre eficiência na prevenção e repressão das atividades criminosas de grupos organizados, e a proteção às garantias individuais dos cidadãos, as circunstâncias admitem tratamento especial a certos indivíduos.

A presunção de inocência não representa óbice à adoção da medida restritiva, por não importar na sanção por crimes hipoteticamente praticados, não se alterando o status jurídico do confiscado, tendo em vista que a perda de bens alargada não se traduz em condenação do agente, sem culminar na supressão da sua liberdade e na suspensão dos seus direitos políticos. O objetivo do confisco alargado é desconstituir uma situação patrimonial ilícita, proporcionando reparo, no contexto da criminalidade organizada, aos danos difusos decorrentes dessa modalidade criminosa. Tem, ainda, uma finalidade preventiva, ao evitar que o agente que, de acordo com as circunstâncias, preferencialmente objetivas, leva estilo de vida inclinado ao crime e condenado por um delito grave com intuito lucrativo tenha a sua disposição bens ou valores que poderão ser empregados no cometimento de novas infrações penais.

Saliente-se que nem mesmo a previsão no estatuto repressivo e a sua aplicação por um juízo penal têm a aptidão de afastar a natureza civil do instituto. Como exposto, a Constituição Federal lançou mão de tratamento semelhante entre o instituto do confisco e a obrigação de reparar o dano. Ambos não se submetem ao princípio da responsabilidade pessoal, motivo pelo qual não podem ter natureza jurídica penal ou de sanção penal. Aliás, tanto o confisco como a obrigação reparatória não se extinguem com a prescrição punitiva ou executória do Estado, o que corrobora com o argumento supra.

Como visto o princípio da proporcionalidade é meio adequado para equilibrar o conflito de bens jurídicos constitucionais colidentes na hipótese. O patrimônio ilícito a ser declarado perdido ofende a outros bens jurídicos de índole constitucional, como a vida, a função social da propriedade, a ordem econômica, a segurança pública e a saúde pública, de maneira que se legitima a modulação da presunção de inocência no que tange a perda de bens alargada, desde que a restrição patrimonial se atenha a evitar o uso do lucro em outras atividades criminosas.

Atentando-se o legislador ordinário à obediência ao princípio do devido processo legal, por meio de previsão legislativa que estabeleça critérios que guardem relação com o que a essência do confisco alargado tem como escopo, seguramente não haverá conflitos da medida com a ordem constitucional.

Todavia, o modelo de perda de bens alargada introduzido pela Lei n. 13.964/2019 (Pacote Anticrime) trará enormes discussões à baila, tendo em vista que o legislador ordinário não teve o cuidado de estabelecer critérios restritos à sua aplicação, o que poderá ocasionar a descaracterização do instituto, aumentando para além do necessário sua possibilidade de incidência. Mais do que isso, a discussão sobre a ilicitude dos bens a serem perdidos paralela a ação penal milita contra o modelo implementado.

\section{REFERÊNCIAS}

ANDRADE, José Carlos Vieira de. Os direitos fundamentais na Constituição portuguesa de 1976. Coimbra: Almedina, 1987 In: MENDES, Gilmar Ferreira. BRANCO, P. G. G. Curso de Direito Constitucional - 13. ed. São Paulo: Saraiva, 2018.

BASSO, Maristela. A lei anticorrupção é a melhor alternativa para as empreiteiras. Disponível em: http://www.justificando.com/2015/03/03/a-lei-anticorrupcao-e-a-melhor-alternativa-para-asempreiteiras/. Acesso em: 14 abril. 2020 às 12:15

BARROS, Lavagem de Capitais - Crimes, Investigação, Procedimento Penal e Medidas Preventivas - Edição Revista, Atualizada e Ampliada. São Paulo: Juruá Editora, 2017. 
BARROS, Marco Antonio de. Lavagem de capitais e obrigações civis correlatas: com comentários, artigo por artigo, à Lei 9.613/1998. $3^{\text {a }}$ ed. rev., atual. e ampl. São Paulo: Editora Revista dos Tribunais, 2012.

BARROSO, Luís Roberto. Curso de direito constitucional contemporâneo: os conceitos fundamentais e a construção do novo modelo. 5. ed. São Paulo: Saraiva, 2013.

BEZERRA, Marcelo Lauande. A experiência italiana no confisco de bens de integrantes de grupos mafiosos. Revista da AGU, Brasília-DF, v. 14, n. 04, p. 179-192, out./dez, 2015. Disponível em: https://seer.agu.gov.br/index.php/AGU/article/view/590. Acesso em: 15 out. 2019.

BITENCOURT, Cezar Roberto. Tratado de direito penal. Parte Geral. v. 1. 22a ed. rev., amp., atual. São Paulo: Saraiva, 2015.

BRASIL. SUPREMO TRIBUNAL FEDERAL. RE 543.974/MG, rel. Eros Grau, data de julgamento: 25 mar. 2009.

COMPARATO, Fabio Konder. A afirmação histórica dos direitos humanos, $11^{\mathrm{a}}$ ed. São Paulo: Saraiva, 2017.

CORREIA, João Conde. Da proibição do confisco à perda alargada. Lisboa: INCM, 2012.

CORTESI, Maria Francesca. Confisca di prevenzione "antimafia" e confisca "allargata": rapporti ed interferenze processual - Archivio Penale 2014, n. 3. Disponível em:

http://www.archiviopenale.it/File/DownloadArchivio?codice=29420bc2-0ef2-4ab1-99cae44f6461156d. Acesso em: 17 out. 2019.

CUNHA, José Manoel Damião. Perda de bens a favor do Estado. Arts. $7^{\circ}-12$, da Lei n ${ }^{\circ}$ 5/2002, de 11 de Janeiro (Medidas de Combate à Criminalidade Organizada e Económico-Financeira). In: Medidas de Combate à Criminalidade Organizada e Económico-Financeira. Centro de Estudos Judiciários. Coimbra: Coimbra, 2004.

ESSADO, Tiago Cintra. A perda de bens e o novo paradigma para o processo penal brasileiro. 2014. Tese Doutorado em Direito Processual. Faculdade de Direito da Universidade de São Paulo. São Paulo: 2014. Disponível em: <http://www.teses.usp.br/teses/disponiveis/2/2137/tde11022015-135202/>. Acesso em: 30 mai. 2019.

EUROPA. EUROPEAN COURT OF HUMAN RIGHTS. Phillips v. The United Kingdom Application no. 41087/98

EUROPA. EUROPEAN COURT OF HUMAN RIGHTS. Butler v. United Kingdom Application no. 41661/98

FERNANDES, Antonio Scarance. O papel da vítima no processo penal. São Paulo: Malheiros, 1995 In: ESSADO, Tiago Cintra. A perda de bens e o novo paradigma para o processo penal brasileiro. 2014. Tese Doutorado em Direito Processual. Faculdade de Direito da Universidade de São Paulo. São Paulo: 2014. Disponível em: <http://www.teses.usp.br/teses/disponiveis/2/2137/tde- 11022015-135202/>. Acesso em: 30 mai. 2019. 
GRECCO, Rogério. Curso de Direito Penal Parte Geral v.1. 17ª Ed. rev., amp., atual. Niterói: Editora Impetus, 2015.

GUERRA FILHO, Willis Santiago. Princípio da proporcionalidade e teoria do direito in Direito Constitucional/Estudos em homenagem a Paulo Bonavides. São Paulo: Editora Malheiros, 2001

HESSE, Konrad. Temas Fundamentais do Direito Constitucional. 1ªed. São Paulo: Saraiva, 2009.

ITÁLIA. Cass., Sez. V, 16 maggio 2014 (dep. 22 luglio 2014), n. 32353, Pres. Dubolino, Rel. Guardiano, Imp. G.M.

LINHARES, Sólon Cícero. Os limites do confisco alargado. RJLB, Ano 5, nº 2, 2019. Disponível em: http://www.cidp.pt/revistas/rjlb/2019/2/2019_02_1731_1803.pdf. Acesso em 01 out. 2019.

LINHARES, Sólon Cícero; CARDELLI, Luiz Henrique. O confisco alargado de bens como instrumento frente à criminalidade transnacional. Revista Jurídica da Procuradoria-Geral do Distrito Federal, Brasília, v. 41, n. 2, p. 121 - 142, jul./dez., 2016. Disponível em: http://revista.pg.df.gov.br/index.php/RJPGDF/article/download/331/242. Acesso em: 23 set. 2019.

LÔBO, Paulo. Direito Civil. Coisas. São Paulo: Saraiva, 2015 In: TARTUCE, Flávio Barros. Manual de Direito Civil. $8^{a}$ ed. rev., atual., e ampl. São Paulo: Editora Método, 2018.

MENDES, Gilmar Ferreira. BRANCO, P. G. G. Curso de Direito Constitucional - 13. ed. São Paulo: Saraiva, 2018.

MILONE, Sofia. La confisca allargata al banco di prova della ragionevolezza e della presunzione di innocenza. 2018. Disponível: http://www.lalegislazionepenale.eu/wpcontent/uploads/2018/06/Milone-approfondimenti-1.pdf. Acesso em: 17 out. 2019.

MINISTÉRIO DA JUSTIÇA E SEGURANÇA PÚBLICA. Projeto de lei anticrime. Disponível em: https://www.justica.gov.br/news/collective-nitf-content-1549284631.06/projeto-de-leianticrime.pdf. Acesso em: 24 abr. 2019.

MINISTÉRIO PÚBLICO FEDERAL. Dez Medidas Contra a Corrupção. Disponível em: 1http://www.dezmedidas.mpf.mp.br/campanha/documentos/medidas-anticor rupcao_versao2015-06-25.pdf. Acesso em 27 jul. 2019.

MIRABETE, Julio Fabbrini; FABBRINI, Renato N. Manual de direito penal. Parte Geral. Vol. 1. 31 a ed. rev. e atual. São Paulo: Atlas, 2015.

MIRANDA, Maria Bernadete; MIRANDA, Fernando Silveira Melo Plentz. Aspectos Emergentes do Princípio da Dignidade da Pessoa Humana na Constituição Italiana e Brasileira. Revista Virtual Direito Brasil, v. 8, $\mathrm{n}^{\circ}$ 1, 2014. Disponível em:

http://www.direitobrasil.adv.br/arquivospdf/revista/revistav81/artigos/bf.pdf. Acesso em: 14 abr. 2020.

MORAES. Guilherme de la Peña. Curso de Direito Constitucional. 10ª Ed. São Paulo: Editora Atlas, 2018. 
MORAES, Maurício Zanoide. Presunção de inocência no processo penal brasileiro: análise de sua estrutura normativa para a elaboração legislativa e para a decisão judicial. Rio de Janeiro: Lumen Juris, 2010.

OCDE. ORGANIZAÇÃO PARA A COOPERAÇÃO E DESENVOLVIMENTO ECONÓMICO. Confiscation of instrumentalities and proceeds of corruption crimes in Eastern Europe and Central Asia. Disponível em: https://www.oecd.org/corruption/acn/OECD-Confiscation-ofProceeds-of-Corruption-Crimes-ENG.pdf. Acesso em: 19 set. 2019.

PARLAMENTO EUROPEU E CONSELHO DA UNIÃO EUROPEIA. Diretiva 2014/42/EU. Disponível em: https://eur-lex.europa.eu/legalcontent/PT/TXT/HTML/?uri=CELEX:32014L0042\&from=EN. Acesso em: 20 set. 2019.

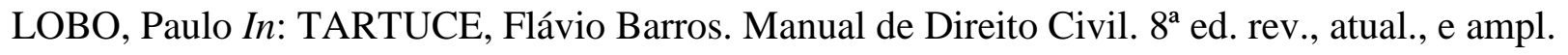
São Paulo: Editora Método, 2018.

PEZZOTTI, Olavo Evangelista. Apontamentos sobre o confisco nos crimes de tráfico de entorpecentes e de lavagem de dinheiro. Revista Fórum de Ciências Criminais - RFCC - ano 6, n. 11, p. 61-101, jan./jun, 2019. Disponível:

https://www.academia.edu/39883033/Apontamentos_sobre_o_confisco_nos_crimes_de_tr\%C3\% A1fico_de_entorpecentes_e_de_lavagem_de_dinheiro

PIOVESAN, Flávia. Direitos humanos e justiça internacional: um estudo comparativo dos sistemas regionais europeu, interamericano e africano. $2^{\mathrm{a}}$ ed. rev. ampl. e atual. São Paulo: Saraiva, 2018.

PORTUGAL. Tribunal Constitucional de Portugal. Acórdão 392/2015. Disponível em: https://www.tribunalconstitucional.pt. Acesso em: 18 out 2019.

PRADO, Luiz Regis. Direito Penal Econômico. $6^{\mathrm{a}}$ ed. rev., atual. São Paulo: Editora Revista dos Tribunais, 2015.

SANTOS, Juarez Cirino dos; SANTOS, June dos. Reflexões sobre Confisco Alargado. Boletim do IBCCRIM. ano 23, n. 277, 2015. Disponível em: https://www.ibccrim.org.br/boletim_ artigo/5679-Reflexoes-sobre-confisco-alargado. Acesso em 14 set. de 2019

SILVA, Cristian Kiefer da; JÚNIOR, Luiz Antônio Soares; PEGO, Anne Vieira Teodorak. Os Quarenta Anos da Constituição Portuguesa e os Direitos Humanos Fundamentais no Brasil e em Portugal: Um Panorama. Caderno do Programa de Pós-Graduação Direito/UFRGS. v. 13, no 2 , 2018. Disponível em: https://seer.ufrgs.br/ppgdir/article/view/81006. Acesso em 14 abr. de 2020

SIMONATO, Michele. Confiscation and fundamental rights across criminal and non-criminal domains. ERA Forum (2017) 18:365-379 DOI 10.1007/s12027-017-0485-02017. Disponível em: https://link.springer.com/article/10.1007/s12027-017-0485-0. Acesso em: 21 set. 2019.

SARLET, Ingo Wolfgang; MARINONI, Luiz Guilherme; MITDIERO, Daniel. Curso de direito constitucional. $7^{\text {a }}$ ed. São Paulo, 2017. 
STRECK, Lênio Luiz. A dupla face do princípio da proporcionalidade: da proibição de excesso (Übermassverbot) à proibição de proteção deficiente (Untermassverbot) ou de como não há blindagem contra normas penais inconstitucionais. Brasília: Revista Jurídica Virtual, vol. 2, n. 13, junho/1999

TARTUCE, Flávio Barros. Manual de Direito Civil. $8^{a}$ ed. rev., atual., e ampl. São Paulo: Editora Método, 2018.

TAVARES, André Ramos. Curso de Direito Constitucional. 10ª ed. rev., e atual. São Paulo: Saraiva, 2012.

VIEIRA, Roberto D'Oliveira. Análise de direito comparado do confisco alargado: aportes da perda alargada para o Brasil. Tese de Mestrado em Direito. Universidade Católica de Brasília. Brasília: 2017. Disponível em: https://bdtd.ucb.br:8443/jspui/handle/tede/2337. Acesso 09 set. 2019. 